\title{
GOVERNMENTAL FARM CREDIT AND TENANCY
}

\author{
WIIIIAM G. MURRAY*
}

The battle waged by Congress against farm tenancy started years ago. In recent years it has been an uphill struggle because tenancy instead of decreasing has been steadily gaining. Far from discouraged, however, Congress has redoubled its efforts to make the typical farmer in this country an owner-operator. Of the various measures enacted to keep ownership open to tenants, those providing farm credit have been the most important.

Has governmental farm credit been used successfully in promoting ownership by farmers? To put the question in another way, would tenancy be more prevalent if the federal and state governments had kept their hands off farm credit? Let us see what kind of answer can be given to this query.

In tackling our problem, we shall break it into three stages: the first, that of governmental land credit in the period 1787 -1820; the second, developments beginning about 1900, including the creation of the Federal Farm Loan System and state farm credit schemes, and the efforts of the federal government to settle farmers on reclamation projects; and finally, the last stage, now in its infancy, which begins with legislation in 1933. As we take up each of these stages the discussion will turn first to the kind of credit provided, next to the use made of the credit by farmers, and then to an appraisal of results.

\section{Governmental CRedit, First Stage, I787-1820}

Our first section, concerning the distant past, starts with the credit offered by the government in the sale of public land shortly after the Revolutionary War. At this time the sale of public land was looked upon as a source of revenue for the government. But Congress, in this early period, realized that many settlers were not able to buy land without credit. To meet this difficulty the land was sold with a down payment, the remainder to be paid later. The manner in which the terms were gradually liberalized is particularly pertinent in view of the action of Congress

- B.A., 1924, Coe College; M.A., I925, Harvard University; Ph.D., 1932, University of Minnesota. Professor of Agricultural Economics, Iowa State College. During r935-36, Chief Economist, Division of Finance and Research, Farm Credit Administration. Author of bulletins on farm finance published by Iowa Agricultural Experiment Station.

This article will be listed as Journal Paper No. J. 497 of the Jowa Agricultural Experiment Station, Ames, Iowa, Project No. 20. 
in recent years. Treat, in his book, The National Land System, 1785-1820, summarizes the early legislative enactments bearing on farm credit as follows: ${ }^{1}$

"A gradual advance toward the establishment of the credit system is noticeable. In 1785 immediate payment was insisted upon; in 1787 three months credit was allowed; in $179 \mathrm{I}$ a credit of two years was suggested on large purchases; and in 1796 a year's credit was offered, and the end was not yet."

The most important piece of farm credit legislation in the early period came in 1800. In this year a bill was passed that extended the period of credit from one to four years and at the same time reduced the minimum size tract sold from 640 to 320 acres. As Treat says,

"The four year credit, denied in 1797 , was now granted. All prospective land purchasers were enthusiastic over that feature. But there were men level-headed enough to prophesy the result of such an inducement to speculation or to over-extensive purchases by the actual settler."2

According to this new act, the purchaser paid one-fourth of the purchase price within 40 days, another one-fourth at the expiration of two years, another at the end of three years and the final payment of one-fourth at the end of four years. Interest of six per cent was charged on the balance outstanding at any time. A discount of eight per cent was allowed on all amounts paid before due. The minimum price for land was $\$ 2.00$ an acre at this time, not including discounts allowed for paying cash in advance nor for any discount obtainable by using evidences of public debt in payment.

In the years that followed increasing use was made of the credit system by purchasers of land but, because of difficulties in collecting the amounts due, Congress in 1820 repealed the credit provisions. In their place, Congress stipulated cash sales only but at a lower price: $\$ 1.25$ an acre in contrast to the $\$ 2$ minimum with discounts which prevailed earlier. From this time onward until after Igoo the federal government was out of the farm credit business. During a major portion of this period Congress, on the other hand, was doing its best to give each settler a foothold on the land; promoting ownership either by reducing the price of land as in the Act of 1820 , by granting pre-emption rights as in the Act of 1841 , or finally by extending settlers the right of homestead according to the Act of 1862 . In each successive enactment the farmer's path of ownership was made easier.

But how did the credit system prior to $x 820$ work? Very badly say the students of that period. Hibbard says: ${ }^{3}$

"The credit system had proved a failure. It had not been a source of great revenue for the treasury, it had not promoted the interests of the settlers, and it had not prevented speculation. It had created a large class of landholders so hopelessly in debt to the government that it took the government twelve full years to clear away the wreckage of the credit system."

${ }^{1}$ Treat, The National Land System, I785-1820 (1910) 90.

IId. at 98.

${ }^{3}$ Hrbiard, A History of the Public Land Policies (1924) 100. 


\section{According to Treat, 4}

"The result was that on January $x, x 820$ the total land sales were estimated at $\$ 44,563,254$, and of this sum $\$ 21,799,562$ were due from the purchasers:"

What amounts almost to official condemnation of the whole business was voiced years later by Donaldson, a member of the Public Land Commission, in his exhaustive treatment of public land policies and activities. He says: ${ }^{5}$

"The disastrous credit system spread over Ohio, Indiana, Illinois, Missouri, Alabama, Mississippi, Louisiana, and Michigan."

During the years 1800 to I 820 many of the credit payments came due. In many instances, similar to those of recent years, payment was evidently either impossible or difficult for the purchaser because Congress was repeatedly called upon to enact relief legislation. ${ }^{6}$ The long list of legislative enactments for the benefit of the indebted land owners has, in many respects, much in common with Congressional action during the depression years more than a century later. Between 1806 and 1820 , according to Treat, ${ }^{7}$ a total of ${ }^{3} 3$ separate and distinct relief acts were passed for the benefit of those in debt to the government for the purchase of land. These acts, for the most part, were moratoria, extending the date when the land would otherwise return ta the government. As stated in the act, if the purchaser did not make the final payment one year after it was due the land was to be forfeited to the government. As the end of the year of grace approached many purchasers realized that they were not going to be able to pay the amount due. To assist these purchasers in holding their farms, Congress extended the period of grace, in the majority of instances for a period of three years. Sales under the Act of 1800 did not begin until 180I. For purchasers who bought on credit in $180 \mathrm{r}$ the year of grace expired in 1806. And in this same year we find that the first. of the thirteen relief acts prior to $\mathrm{r} 8 \mathrm{2I}$ was passed.

After the credit provisions were repealed in 1820 , Congress was still faced with requests for relief from the purchasers who owed the government over $\$ 21,000,000$. As Hibbard mentioned in the quotation given above, twelve years elapsed before Congress was able to stop legislating in behalf of this group. Eleven acts were placed on the statute books in the period r82I-1832, as listed by Treat, ${ }^{8}$ solely for the purpose of liquidating the debt outstanding in 1820 . One of the novel methods of reducing this debt was by relinquishment. For instance, a purchaser of 640 acres who paid down one-fourth of the purchase price but could not make any further payments on the remainder was allowed to keep r6o acres clear of debt by relinquishing 480 acres to the government.

\footnotetext{
- TrEat, op. cit. supra note I, at I4I-I 42 .

'Donaldson, The Public Domain (Pub. Land Comm'n, Washington, D. C., Rev. Ed. 1884 ) 205.

'Ibid. The author says: "Petitions, resolutions, legislative enactments, and personal applications for relief from the pressure of land purchases from the government under the credit system resulted in various acts of relief."

"TREAT, op. cit. supra note I, at I43. "Id. at I6I.
} 
What caused the downfall of the first important attempt of the government to extend farm credit? Of primary significance was the trend toward free land for settlers and away from land sales for revenue. One measure of this trend can be seen in the rapid reduction in the minimum size of tract sold. According to Hibbard $^{9}$

"The minimum amount offered had dropped from the whole townships, and whole sections in alternate townships, provided by the Land Ordinance of 1785 , step by step, with quarter townships and single sections in 1796 , half sections, quarter sections, eighty acre tracts, and finally, in 1832 , to forty acre tracts. The quarter section provision was achieved in 1804 while eighty was allowed in part in 1817 and universally in $1820 . "$

This reduction in size coupled with the reduction in price resulted in the availability to the settler of an eighty acre farm for $\$ 100$; a sum so small that credit no longer was a prominent factor. In reality, the credit system was replaced by conditions making it unnecessary.

Another circumstance which hastened the repeal of the credit provisions was the boom and depression between $\mathrm{r}^{8} \mathrm{1}_{5}$ and $\mathrm{r}_{220}$. The events of these years are briefly but clearly set forth by Hibbard as follows: ${ }^{10}$

"The sale of lands during the four years preceding 1820 increased by leaps and bounds. Debts on public land were increasing rapidly as were also the arrears which resulted in many forfeitures. During the four years from 1815 to 1818 , inclusive, the amount due the government increased from $\$ 3,042,6 \mathrm{r} 3.89$ to $\$ 16,794,795$. I4. The panic of $x 8 \mathrm{rg}$ found the land debtors, therefore, in bad circumstances."

In the light of these conditions, the Act of April 24, 1820, reducing the price of land to $\$ 1.25$ an acre minimum, reducing the minimum size tract to eighty acres, and abolishing the credit features allowed in previous acts, can be seen as a direct product of the times.

As a summary of this early venture in farm credit, the term "unsuccessful" can be properly applied. The government did not benefit as expected from revenue and the purchasers evidently did not have easy sailing in view of the numerous relief acts which were passed in their behalf. But that is not the whole story by any means. With the Louisiana Purchase in 1803 and the opening up of the territory west of the Allegheny Mountains at this time, settlers could point out that the government had so much land there was no justification for a price as high as $\$ 2.00$ an acre. In fact, the availability of new land on such a large scale undermined the credit system and the efforts of the government to convert its land holdings into revenue.

In the debt relief acts of this early period there exists an object lesson which should be studied carefully by those concerned with the present day efforts of the government in making farm credit available. Farm credit and politics did not mix well at the beginning of the last century. With a large number of individual

\footnotetext{
${ }^{9}$ Hibbard, op. cit. supra note 3 , at 75.

${ }^{20} 1 d$. at 97 .
} 
farmers owing the government and at the same time electing their representatives to Congress, these representatives found it extremely difficult to press their constituents, the individual farm debtors, for payment.

\section{Governmental Credit, Second Stage, rgo0-i932}

From I820 to the turn of the next century, the government was disposing of the public domain on terms that made farm credit unnecessary. By rgoo, however, forces were at work which soon brought the question of credit into the limelight. Free land in the more productive areas was gone, prices were rising, and as a consequence, the purchase price of a farm was beginning to look formidable to the prospective buyer.

What happened at the beginning of the present century is strikingly portrayed in Table I. In this table are value figures giving a cross-section of conditions at ro year intervals. Practically no change occurred between 1860 and Ig00 for the United States as a whole. Although the value per acre of land and buildings rose from $\$ 16.32$ to $\$ 19.81$, the size of farm was decreasing so that the average farm value actually decreased from $\$ 3,25 \mathrm{I}$ in 1860 to $\$ 2,896$ in I900. In marked contrast to the stable values prior to Ig00 is the huge increase which was registered in the Census of rgro. A farm, including land and buildings, worth $\$ 2,896$, jumped to $\$ 5,47$. The value of land, by itself, rose in this decade from $\$ 15.57$ to $\$ 32.40$ an acre, or more than 100 percent. It was this phenomenal increase in values that forced the farm credit issue into the Congressional spotlight.

TABLE I*

Value of Farms (Land and Buildings) and Tenant Farmers as Percent of alt Farmers. Federal Census I860-I935

\begin{tabular}{|c|c|c|c|}
\hline \multirow{3}{*}{$\begin{array}{l}\text { Census } \\
\text { Year } \\
1860 . .\end{array}$} & \multicolumn{2}{|c|}{ Value of Farm Land and Buildings } & \multirow{4}{*}{$\begin{array}{c}\text { Tenant Farmers as } \\
\text { Percent of all } \\
\text { Farmers }\end{array}$} \\
\hline & Per Acre & Per Farm & \\
\hline & $\$ 16.32$ & $\$ 3,25 \mathrm{I}$ & \\
\hline$\Sigma 870$. & . $\quad 18.26$ & 2,799 & \\
\hline 1880. & . . $\quad 19.02$ & 2,544 & $25.5 \%$ \\
\hline 1890. & $2 I \cdot 3 I$ & 2,909 & 28.4 \\
\hline 1900. & . $\quad 19.8 \mathrm{I}$ & 2,896 & $35 \cdot 3$ \\
\hline xgro. & 39.60 & 5,471 & 37.0 \\
\hline I920. & 69.38 & 10,284 & $3^{8 . x}$ \\
\hline I930. & . $48.5 ?$ & $7,6 \mathrm{I}_{4}$ & 42.4 \\
\hline r935. & $\therefore \quad 3^{1.16}$ & 4,823 & 42.1 \\
\hline
\end{tabular}

- Compiled from tables in U. S. Bureau of the Census, U. S. Census of Agruculture, 1935 (1937).

The increase in values was all the more significant because of the increase in tenancy which was in progress. In I880, according to the Federal Census for that year, only $25.5 \%$ of the farms were operated by tenants, in I 890 the percentage had risen to 28.4 and by 1900 , chiefly as a result of the severe depression of the nineties, $35.3 \%$ of the farms were tenanted. Although the price level was on the upgrade 
during the first decade of the present century and conditions were relatively prosperous, tenancy continued to increase, the percentage in I9Io being 37. Consequently, with values going up and a larger number of farmers in the tenant class, more and more pressure was being brought to bear on provisions for farm credit. Whereas, formerly, farmers desiring ownership could turn to the free land on the frontier, now they had to finance the purchase of higher priced land or else remain in the tenant class.

The fact that land values rose from Ig00 to I9ro was in itself a cause for demands for additional credit. Each purchase in Igro took roughly twice as much credit as in 1900 if the buyer borrowed the same percentage of the purchase price. Then, too, as a psychological reason, many tenant farmers as they watched land values go up year by year, undoubtedly wished they had purchased before land went up and, rightly or wrongly, blamed the credit system for not making funds more plentiful with which to buy land.

The stage was set for agitation to obtain farm credit aid through Congress. Although a long period elapsed before the legislation was finally passed, the agitation persisted as well as the basic reason which gave rise to it. ${ }^{11}$ In rgo8 the Country Life Commission appointed by President Theodore Roosevelt reported the need for improved credit facilities. In I9r2, the Southern Commercial Congress, in convention at Nashville, Tennessee, appointed a group to study farm credit abroad; this was known as the American Commission. In I9I3, Congress authorized the appointment of another group, called the United States Commission, to study farm credit abroad. These two commissions, which jointly investigated European methods of extending farm credit, made their report late in r9r3. From this time onward until the Federal Farm Loan Act was passed in rgr6, the air was filled with speeches on farm credit and the presses were busy turning out a flood of farm credit literature..$^{12}$

One of the outstanding characteristics of the drive for farm credit legislation was: the emphasis placed on cooperative agencies. In Europe, cooperative farm credit agencies were numerous and successful. This fact became the chief topic in discussions of proposed farm credit legislation in this country. The two commissions which went to Europe had as their specific purpose a study of cooperative credit agencies of European farmers. In the Federal Farm Loan Act this cooperative idea is dominant in part but not throughout. Two compromises with the strict cooperative idea were made. In the first place, the government, in exchange for granting the tax-exemption privilege to Federal Land Bank bonds, retained powers of supervision, and, of most importance, the final say on appraisals; that is, the government through the Federal Farm Loan Board could determine the maximum amount

\footnotetext{
${ }^{11}$ See Morman, Farm Credits in the United States and Canada (I924) c. $x$.

12 Among the more important books published during this period are the following: Herrick, RurAL Credits (I914); Morman, The Princteles of Rural Credits (1915); Morgan, Land Credits (1915). The report of the two commissions should be mentioned also; it was issued in November, I913 as SEN. Doc. No. 214, G3rd Cong., Ist Sess.
} 
loaned on any given piece of land. As a result, though the local national farm loan associations were cooperative institutions, they were not free to act independently. If they wished to make a loan, the maximum amount of this loan was determined by federal appraisers over which the local cooperative had no jurisdiction. The second compromise was the establishment of joint stock land banks, privately capitalized institutions, with the privilege of issuing tax-exempt bonds similar to Federal Land Banks. In reality, the Act set up a private system to compete with the cooperative banks.

The cooperative features of the Federal Farm Loan Act should be kept well in mind because they provide a marked contrast to some of the more recent legislation. Furthermore, they will probably constitute an important part of the debate in future legislation.

Three features of the Federal Farm Loan Act not mentioned thus far are the amortization plan, long term provisions, and the arrangements for securing low interest rates. These points in addition to the cooperative idea were so widely discussed at the time the subject was before Congress that they became almost the purpose of the legislation. What the farmers needed, according to the typical agricultural spokesman of the day, were lower interest rates and a longer time in which to pay the mortgages on their land. Mortgage agencies and commercial banks, lending on land security at the time, were unable or unwilling to make long term loans to farmers; instead of thirty-year loans, loans of only five years were being made. Moreover, interest rates in the south and west were admittedly high in comparison with the east and central west. The Act that was passed met these issues squarely; loans could be made for periods as long as forty years, the loans to be paid on an amortization basis, an equal amount or percentage paid on the principal each year; and finally in order to lower interest rates, the mortgages were to be pooled by each Federal Land Bank and tax-exempt bonds issued to obtain funds to lend to the farmers.

Behind the pressure in Congress for long-term, low-interest farm credit, there existed, we must not forget, the rise in land values which started roughly in rgoo and by Igro reached the heights indicated in Table $\mathbf{I}$. Longer terms and lower interest rates were considered, and rightly so, as measures that, for the time being at least, would make it easier for farmers to finance the purchase of land or to refinance mortgages already existing. Prior to Igoo, farmers expected and did often pay mortgages when they came due with proceeds from their farming operations. But when the value of land went up as it did after 1900 , the three and five year mortgages were too big to be paid off when they came due. Hence, we had a basic reason for the clamor for loans with longer terms.

To go back to the Federal Farm Loan Act ${ }^{13}$ itself, we find the purposes for which loans could be made are as follows:

\footnotetext{
${ }^{18}$ Act of July 17, 1916, 39 STAT. 360, 12 U. S. C. c 7.
} 
"(a) To provide for the purchase of land for agricultural uses.

(b) To provide for the purchase of equipment, fertilizers, and livestock necessary for the proper and reasonable operation of the mortgaged farm; the term 'equipment' to be defined by the Federal Farm Loan Board.

(c) To provide buildings and for the improvement of farm lands; the term 'improvement' to be defined by the Federal Farm Loan Board.

(d) To liquidate indebtedness of the owner of the land mortgaged incurred for agricultural purposes, or incurred prior to the organization of the first farm-loan association established in and for the county in which the land is situated."

The first purpose of loans listed in the Act is for the purchase of land. This was an important reason for the establishment of farm credit facilities by the government. $^{14}$ It was hoped by those who backed this legislation that, through these new channels of credit, tenants would be able to attain ownership on more advantageous terms than formerly and that as a consequence tenants in large numbers would use the new credit facilities to become farm owners.

Those who expected the Federal Loan system to make the majority of its loans for the purchase of land were disappointed. Although the percentage devoted to this purpose in the first five years amounted to 18 , this proportion has not been equalled since (see Table 2). And, unfortunately for those who bought, the 82 million loaned for land purchase in the I9r7-2I period represented in many instances boom-time purchases. Of the twenty years represented in Table 2 , the last

\section{TABLE 2}

\section{Land Purchase Loans as Percentage of All Loans Made by Frderal Land Banks} and Land Bank Commisstones* rgr7-1936

\begin{tabular}{|c|c|c|c|}
\hline & $\begin{array}{c}\text { Percent of Loan Proceed } \\
\text { Used to Purchase Land } \\
\text { and Redeem from } \\
\text { Foreclosure } \\
18.0 \%\end{array}$ & $\begin{array}{l}\text { Total Loans } \\
\text { Made } \\
02,048,728^{*} *\end{array}$ & $\begin{array}{l}\text { Amount Used for } \\
\text { Land Purchase } \\
\$ 16,658,77 \mathrm{r}^{*}\end{array}$ \\
\hline 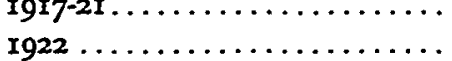 & $\begin{array}{l}18.0 \% \\
2.2\end{array}$ & $\begin{array}{c}92,048,728 \\
224,301,400\end{array}$ & $4,934,63 I$ \\
\hline $23 \ldots \ldots \ldots \ldots \ldots \ldots \ldots \ldots$ & 3.8 & $x 92,083,015$ & $7,299,155$ \\
\hline $24 \ldots \ldots \ldots$ & 6.3 & $r 65,509,845$ & $10,427,120$ \\
\hline 25 . & 9.5 & $\mathrm{I} 27,355,45^{\mathrm{I}}$ & $12,098,768$ \\
\hline
\end{tabular}

- This rable made up from data appearing in Annual Reports of the Farm Credit Administration and in the Farm Credit Quarterly, September 30, 1936, Table 9, p. 22. Figures for the years 1917-1932 represent all loans submitted for bond collateral; for the years 1933-1936, the figures are estimates based on loans made during a portion of cach of these years, excepting 1936 for which all loans during the year were used. For the years I933-36 loans made by the Land Bank Commissioner are included along with those of the Federal Loan Banks.

* Yearly average. Total for five year period is $\$ 460,243,641$, of which $\$ 82,843,855$ was used for land purchase.

${ }^{21}$ Holt, The Federal Farm Loan Bureat. Its History, Activities and Organization, INsr. Fon GoverNmegnt Rresearch, Service Monographs of the U. S. Government, No. 34 (1924). Holt says, on p. 5, "To reduce these (interest) rates and to have long-term credit facilitics always available when needed by the farmers, it was generally deemed necessary to have a rural credit system established and controlled by the national government. If this were done, it was urged that not only would the agricultural community be relieved of a great burden but tenancy would also be stopped; and as a result of these improved conditions the drift of population from the country to the cities, which so alarmed some people, would be ended." 


\begin{tabular}{|c|c|c|c|}
\hline rg26 .................... & II.o & $131,317,715$ & $I 4,444,949$ \\
\hline Ig27 $\ldots \ldots \ldots \ldots \ldots \ldots \ldots \ldots$ & 8.7 & $140,384,200$ & $\mathrm{I} 2,213,425$ \\
\hline rg28 $\ldots \ldots \ldots \ldots \ldots \ldots \ldots \ldots$ & 9.9 & $102,236,400$ & I0,I2I,404 \\
\hline rg29 $\ldots \ldots \ldots \ldots \ldots \ldots \ldots \ldots$ & 14.0 & $64,252,500$ & $8,995,35^{\circ}$ \\
\hline r930 $\ldots \ldots \ldots \ldots \ldots \ldots \ldots \ldots \ldots \ldots$ & 12.9 & $47,97^{1,000}$ & $6,188,259$ \\
\hline $1931 \ldots \ldots \ldots \ldots \ldots \ldots \ldots \ldots \ldots$ & 8.6 & $42,015,300$ & $3,613,316$ \\
\hline r932 $\ldots \ldots \ldots \ldots \ldots \ldots \ldots \ldots$ & 4.6 & $27,569,800$ & $I, 268,2 \mathrm{II}$ \\
\hline $1933 . \ldots$ & 2.9 & 222,446, II I & $6,450,937$ \\
\hline I934 $\ldots \ldots \ldots \ldots \ldots \ldots \ldots \ldots$ & 2.9 & $1,283,503,456$ & $37,22 x, 600$ \\
\hline $1935 \ldots \ldots \ldots \ldots \ldots \ldots \ldots \ldots$ & 10.7 & $445,066,549$ & $47,622,121$ \\
\hline I $936 \ldots \ldots \ldots \ldots \ldots \ldots \ldots \ldots \ldots$ & 14.0 & $\mathrm{r} 86,427,995$ & $26,099,919$ \\
\hline Average and total . & 7.6 & $3,862,684,37^{8}$ & $291,843,020$ \\
\hline
\end{tabular}

three, I934-36, appear to be most satisfactory in the long battle against tenancy. In these recent years, the amounts advanced for land purchase are, in actual amount although not in percentage of amount loaned, far in excess of those of previous years. To account for the increase beginning in 1934, the passage of the Emergency Farm Mortgage Act of $1933^{15}$ providing for the Land Bank Commissioner loans has to be considered. These new loans could be added to Federal Land Bank loans to raise the total amount of credit extended on a farm up to $75 \%$ of the value of the land and buildings. Previous to this time, Federal Land Bank loans were the only loans made and these were restricted then, and still are, to $50 \%$ of the value of the land and $20 \%$ of the value of the buildings. These new loans, consequently, have placed the federally sponsored credit agencies in a much better position to assist farmers in climbing from tenancy into ownership. And the figures show encouraging results.

\section{State Farm Credit, igio-I932}

The same reasons back of the national drive for farm credit legislation stirred many of the state legislatures into action. Putnam in an article in 1915 has summarized the action of the states in these words, ${ }^{16}$

"That the American states are vigorously attacking the agricultural credit problem is evidenced by the number of rural credit measures which have been enacted into law within the last two years. No less than seven states now have comprehensive laws designed to bring about desirable reforms in the land credit system. In seven states there have been enacted laws governing the formation and management of credit unions or cooperative credit associations. The most important legislative measures, however, have been concerned with the problem of land credit reform. Massachusetts, Utah, and Wisconsin have made special provision for the establishment of competitive farm land banks under state supervision; the New York legislature has provided for the organization of the Land Bank of the State of New York, a central institution, to be owned and controlled by local savings and loan associations; while Missouri, Montana, and Oklahoma have abandoned all hope of solving the rural credit problem through private initiative and have adopted modified programs of state loans."

${ }^{24} 48$ STAT. 4 I (1933).

is Putnam, Agricultural Credit Legislation and the Tenancy Problem (1915) 5 AM. EcoN. REv. 805. This article is an excellent statement of the background of both state and federal legislation. The author stresses the importance of rising land values as a basic reason for the agitation for farm credit reform. 
But the actions of these states listed above by Putnam were merely curtain raisers compared to the farm credit legislation passed later by the states of South Dakota, North Dakota and Minnesota. Although these three were not the only ones which tackled the problem later, they went further than any other states. ${ }^{17}$

South Dakota passed a law setting up a Rural Credit system in r91\%. According to Sparks, whose discussion of state farm mortgage ventures is the best treatment of the subject, the loans provided for by the South Dakota law were in many features similar to the loans made by the Federal Land Banks. He says: ${ }^{18}$

"Loans were made in sums of from $\$ 500$ to $\$ 10,000$ on an amortization plan running for not less than five years nor more than thirty years, with prepayment privileges after five years.... The rate of interest to the borrower was to be not less than one-half of $x$ per cent nor more than $1 \frac{1}{2}$ per cent above that contracted to be paid by the State for money borrowed by it."

According to Sparks, whose information is obtained directly from the Annual Reports of the Rural Credit Board, the loans outstanding reached a peak in 1924, the June $3^{0}$ report of that year showing total loans outstanding of $\$ 40,878,683$. Troubles soon beset the South Dakota Rural Credit Board resulting in an investigation and an act of the legislature in 1925 stopping lending activities and providing for liquidation of the system.19

One of the best summaries of the South Dakota experience can be obtained from the balance sheet of the South Dakota Rural Credit Board for a recent year. The balance sheet for June 30, r937 shows bonds outstanding amounting to almost 39 million dollars. As assets to use in paying these bonds the Board has 30 million dollars of real estate, slightly more than one million in loans in foreclosure and slightly less than 6 million in farm loans. In addition ta these assets, miscellaneous items bring the total assets to approximately 39 million dollars. But this is not all; the State of South Dakota through tax levies has advanced the Board almost i7 million dollars plus regular appropriations of $\$ 400,000$. In brief, the deficit of the Rural Credit Board from I9I7 through June 30 , 1937 amounted to $\$ 17,621,762 .^{20}$ In

\footnotetext{
${ }^{17}$ For instance, a bill was introduced in the Iowa legislature in 1915 providing for state farm mortgage banks to be capitalized at not less than $\$ 50,000$; they were to be allowed to issue bonds based on farm mortgages as security. This measure was passed by the House but was turned down by the Senate. Preston, History of Banking in Iowa (1922) 287.

${ }^{23}$ Sparks, History and Theory of Agricultural Credit in the United States (1932) 212.

${ }^{19}$ Sparks has the following to say on the management and the investigation. "The control and management of the Department were centered in a Rural Credit Board consisting of the governor and four members appointed by him. Proper checks were not kept on the activities of this Boars. It was permitted to pursue its optimistic way, with but little public attention centered upon it, until in 1922 the rumor became prevalent that the affairs of the Rural Credit system were not in good condition. Accordingly, in 1925 the legislature authorized an investigation. This investigation, covering the period from August 31, 1917, to June 30, 1926, revealed a deficit of $\$ 3,740,695.50$ and the fact that over \$200,000 had been embezzled by the Treasurer of the Board. ('Report of the Interim Committee to the State of South Dakota and Members and Officers of the Legislature of South Dakota,' Journal of the Senate, 20th Session, 5th Day, 1927, page r07.) In this same connection it is interesting to note that the treasurer made unauthorized deposits to the amount of $\$ 791,725.07$ in banks which were later closed." SpARKs, op. cit. supra note 18 , at 213,214 .
}

${ }^{20}$ S. D. Rural Credit Board, ig37 ANnual Report. 
the words of Sparks, "South Dakota's experience in rural credits has cost her dearly."21

North Dakota embarked on its adventure in farm credit in 19r9. Loans in this instance were made through the Bank of North Dakota which was established by the legislature to make loans of various kinds. Farm loans could be made on an amortization basis for a period not exceeding 30 years. Interest charged at one period was $61 / 2 \%$ with principal payments of $11 / 2 \%$ annually.

Space will permit only a few of the details of the ups and downs of the Bank of North Dakota. After commencing business in I9I9, the first period of bank operation was brought to a stormy close by the recall election of October rg2r. The new administration which took over the Bank proceeded to expand the farm loan business. In 1922, a total of $\$ 3,470,691$ was loaned on farm land. ${ }^{22}$ In commenting on the farm loans made in I922, Tostlebe gives the impression that more money might have, and should have, been loaned. He says: ${ }^{23}$

"It must be noted at this point that a conservative policy of bank management was certain to bring down bitter criticism on the heads of the officials, however justified such a policy might be. However, an examination of the above summary of the farm-loan department's operations for 1922 reveals an unwarranted slowness in making loans. The farmers' need for money was great. Bankruptcies and foreclosures were the order of the day. Yet in the face of this disaster only $\$ 3,470,69 \mathrm{r}$ were paid out in a year's time. Surely few would have the hardihood to say that this was a creditable showing!

"Why did the Bank not make more farm loans in 1922? But two explanations present themselves. One is that the farmers did not care to accept the amount which the new administration offered to loan on their land. The other is that the Bank could not, or would not, digest the loans and close them with dispatch. . . . It appears that conditions were far more favorable for the proper functioning of the farm-loan department in 1922 than ever in the history of the Bank. But the record of loans is on the whole unsatisfactory, especially in view of the urgency of the need, and the opportunities for service at hand."

In the light of the events which have taken place since the quotation above was written, the conservative policy of slowness in making loans was probably justified. Lending farmers enough money to satisfy all their creditors and thereby preventing foreclosure is a long tedious procedure unless the creditors are paid off in full. But if creditors are paid in full, the debtor is left in no better situation than before except possibly in that his interest charges may be reduced somewhat and a variety of creditors replaced by only one. This situation in North Dakota illustrates perfectly the difficulties faced by a state credit agency.

Although the farm loan record of the Bank of North Dakota has been relatively successful compared to other state systems, the depression had its inning. In judging

${ }^{21}$ Sparks, op. cit. supra note 18 , at 218 .

${ }^{2}$ See Tostlebe, The Bank of North Dakota: An Experiment In Agrarian Banking, ColumBIa UNiv. Studies in History, Economics and Public Law, Whole No. 254 (I924). Tostlebe takes his figures from the Report of the North Dakota Industrial Commission for 1922.

Id. at 172-173. 
the North Dakota operations, it must be remembered that in addition to the ravages of the price depression, farmers in North Dakota had a succession of crop failures in the 1930's which almost wiped out what little income they would have had otherwise. Through December 3I, I935, a total of $\$ 40,505,450$ in farm mortgage loans was made. ${ }^{24}$ Of this total almost 23 million dollars was received in payments, chiefly payments resulting from the refinancing of loans with the Federal Land Bank and the Land Bank Commissioner in 1934 and 1935. Loans refinanced in this manner amounted to 18 million dollars; the loss taken by the Bank of North Dakota in the refinancing totaling $\$ 4,470,567$.

At the beginning of 1936 , the Bank had outstanding loans with unpaid principal amounting to $\$ 11,250,213$. Real estate owned was figured at the unpaid principal of the loans made previously on this land, a total of $\$ 6,558,269$. In addition, the Bank had cash on hand for the payment of outstanding bonds, a fund of $\$ 7,855,666$. These are the main asset items of the farm loan department. On the liability side of the ledger, the big item was, on Dec. 3I, 1935, real estate bonds amounting to $\$ 27,411,700$. The total deficit on this date equalled $\$ 7,285,5 \mathrm{r} 4$. To meet this deficit the state had contributed almost 7 million dollars from tax revenue.

In I923 Minnesota followed in the footsteps of the Dakotas by passing the "Rural Credit Act," a law closely paralleling the Federal Farm Loan Act. ${ }^{25}$ Loans were to run for periods not exceeding forty years. The interest rate was not to exceed threefourths of one percent above the interest rate paid by the state for funds borrowed. According to Morman ${ }^{20}$

". . . the Minnesota law aims to encourage the man with little capital to become a farm owner by permitting the bureau to make loans for part payment of the purchase price of improved farm land providing the vendor will take a second mortgage for the unpaid balance of the purchase price."

This is an instance of promoting ownership through farm credit facilities. Another feature of the Minnesota system making the shift from tenancy to ownership less difficult was the provision allowing loans up to $60 \%$ of the appraised value of the land plus $331 / 3 \%$ of the appraised value of the improvements. In brief, Minnesota thought the Federal Farm Loan Act was too conservative. To remedy this defect they set up their own system modeled on the national one but with more liberal loan provisions.

And what has been the history of the Minnesota system? A. G. Black in 1928 wrote as follows:

"The Minnesota department also made many ill-advised loans during its early history. The present administration is conservative, however, and if current policies are continued, there seems to be slight ground for concern as to the ultimate success of the department. Earnings appear sufficient to cover any losses resulting from poor loans."27

\footnotetext{
${ }^{2}$ See N. D. Industrial Comm'n, 1935 Annual Report.

${ }^{z}$ For a brief description of the Minnesota Act, see Morsen, op. cit. supra note 11 , at 189-192.

${ }^{20}$ Id. at $19 \mathrm{I}$.

${ }^{27}$ Black, The Provision for Agricultural Credit in the United States (1928) 43 Q. J. EcoN. I05.
} 
The price decline which set in a few years after this was written put an entirely different ending to the story. We can get an accurate accounting by taking a look at the balance sheet for December 3r, $1934^{28}$

At the close of $x 934$ the bonds outstanding plus other certificates of indebtedness amounted to 66 million dollars. In assets for the retirement of this debt the Department of Rural Credit had mortgage loans totaling almost 33 million and real estate amounting to practically 25 million dollars. Other miscellaneous assets brought the total to $6 \mathrm{I}$ million. The deficit, taking into account other miscellaneous liabilities, was figured at $\$ 6,852,900$. 90 as of the close of 1934 .

Most of the loans made by the Minnesota system were made in the years 1924-26. Of the 13,558 loans made between 1923 and 1933 , a total of 8,415 were made in these three years. No loans were made after $19333^{29}$

Deficits of seventeen, seven and six million dollars for the state credit systems of South Dakota, North Dakota and Minnesota represent, for recent years, a summary of state credit experience. Final losses, of course, will not be available until the heavy holdings of real estate are liquidated. Certain it is, however, that the experience has been costly. The conclusion, for our purposes, is simply that state credit systems are not a satisfactory method of financing farm ownership. Officials in charge of state agencies are too close to the electorate; they carnot, if they will, escape the prevailing optimistic estimation which citizens of any state place in the value of farm land in their commonwealth.

\section{Credit to Settlers on Irrigation Projects}

A localized, but none the less significant, experiment in governmental farm credit is that initiated by the federal government with the passage of the Reclamation Act of Ig02. ${ }^{30}$ This act established a fund supplied by federal receipts from sale of public lands, from oil royalties and from other similar sources. With this fund the Secretary of the Interior was given the power to finance irrigation development. ${ }^{31}$ By xو10 a total of 26 projects were in progress or completed. By 1934 the list had grown to $3 \mathrm{r}$ including 3 that had been abandoned. These were scattered through ${ }_{5} 5$ western states.

A word or two about the cost and repayment will introduce the credit arrangements. By r 934 a total of 228 million dollars had been expended by the federal government. In 1926 Congress charged off practically $\mathrm{I} 6$ million, thus leaving 212 million to be repaid. Payments totaled 56 million dollars up to June 30, 1934, leaving a balance of 157 million outstanding. ${ }^{32}$ Settlers on federal irrigation projects originally were required to pay back the cost over a ten year period without

\$ (Jan. 1935) II THE Liquidator (Minn. Dep't of Rural Credit) No. I. (This issue of The Liquidator was entitled, "Statistical Information, Dec. 31, 1934.")

20Id. at 13. ${ }^{30} 32$ STAT. 388 (1902).

3 Haw and Schmitt, Report on Federal Reclamation (U. S. Dep't of the Interior, 1934) 28. This is a concise appraisal written by two experts called in to make a critical examination of federal reclamation development.

${ }^{89}$ Id. at 29. 
interest. This was changed later, because of difficulties in making payments, to a 20-year payment plan. Still later, payments were scheduled in some cases on a 40-year basis.

The extent to which Congress has acted to ease the terms of payment on federal irrigation projects is readily seen in the following list of legislative enactments. ${ }^{38}$ 19I4. Reclamation Extension Act, which permitted the period of repayments to be extended to 20 years.

1921. Relief to water users on federal projects.

1922. Relief to water users on federal projects.

1923. Relief to water users on federal projects.

1924. Relief to water users on federal projects.

I926. Omnibus Adjustment Act, providing for a charge-off on I7 projects amounting to $\$ \mathrm{r}, 708,0 \mathrm{6} 6$, and the appraisal and sale of excess land.

193r. Relief extended to Uncompahgre project, Colo.

1932. Moratorium on construction charges for $193 \mathrm{x}$ and $x 932$.

1933. Moratorium on construction charges for 1932 and 1933 .

1934. Moratorium on construction charges for 1934 .

The gravity of the situation can be grasped from the following statement on repayments taken from the report referred to above. ${ }^{34}$

"Many of the projects here represented have been in operation for a quarter of a century, yet repayments amount to little more than 25 percent of the obligated cost, ..."

At the root of the trouble, as brought out in the special report to the Secretary of the Interior, is the leniency of the government. Excerpts from this report, quoted below, ${ }^{35}$ summarize in a comprehensive manner the point at issue.

"It is a pertinent fact that, though the reclamation debt is a prior lien on the land, yet in very few cases during the entire history of reclamation has the lien been enforced by legal process, despite thousands of cases of nonpayment. Further, as much as a quarter century ago the reclamation settlers learned that payment could be postponed by appeal to political methods."

"It is impossible to overlook the fact that reclamation repayment is gravely complicated by a spirit of opposition to repayment and a definite movement to bring about cancellation of the Government debt. Indications of such opposition appeared early in the history of the projects. The subsequent years of agricultural depression merely strengthened an opposition already in existence."

"Reclamation experience can leave no doubt as to the necessity of putting an end to continued efforts to postpone and escape payment of reclamation repayment, by the establishment of a clearly defined banking basis for the debt and the application of rigid banking methods for collection. Such a system would also accomplish the essential purpose of taking the subject out of politics."

These are strong words, especially when found in a report published by the government.
${ }^{8}$ Id, at 32-33.
${ }^{34}$ Id. at 86.
${ }^{2} 1 d$. at $92-93$. 
The criticisms leveled at federal reclamation financing in this report might be considered too "cold-blooded," too much like a conservative banking attitude, were it not for one striking weakness in the development. This is the increase in tenancy which has taken place on the projects. In I920 tenant farmers represented $24 \%$ of all farmers on federal reclamation projects, in r925 the number had risen to $33 \%$, and in 1930 the figure had increased again to $36 \% \%^{\circ 8}$ These figures raise an important question as to the government's ability to bring about anything approximating $100 \%$ owner-operation among farmers. With all the assistance that the government has given the farmers on the federal irrigation projects, tenancy, in I930, was almost as high on these projects as for the country as a whole, $36 \%$ as compared to 42.4 .

\section{Governmentai Credit, Third Stage, i933-}

Although we are still too close to recent developments to know whether they are in truth a new and third stage, the legislation of the past five years is sufficiently different from anything in the past to warrant setting it apart. The laws which characterize this new period include two of far-reaching significance. The first is the Emergency Farm Mortgage Act of $1933{ }^{37}$ providing for the Land Bank Commissioner loans. These loans either by themselves or together with the Federal Land Bank loans can, as pointed out earlier, equal $75 \%$ of the value of the land and buildings offered as security by the farmer. Moreover, these loans are not part of the Federal Land Bank or the local loan association system even though these agencies assist in the making of the loans. These loans, on the other hand, are made by the Government of the United States through the Land Bank Commissioner. Consequently, for the first time since I820, the government is again in the farm credit field directly and on an extensive basis.

The second piece of precedent-making legislation was passed by Congress July 22, 1937. This is the Bankhead-Jones Farm Tenant Act, ${ }^{38}$ a clear-cut program of making loans to tenants to buy farms. The loans are to be made only to tenants, and only for the purpose of buying a farm. Again, the loans are a direct advance from the government; in this instance, to be administered by the Secretary of Agriculture on recommendation of county committees. The Act is specific on the maximum amount loanable. It says: ${ }^{\mathbf{3 \theta}}$

"Loans made under this title shall be in such amount (not in excess of the amount certified by the County Committee to be the value of the farm) as may be necessary to enable the borrower to acquire the farm and for necessary repairs and improvements thereon, and shall be secured by a first mortgage or deed of trust on the farm."

1 Id. at 84 .

${ }^{87} 48$ STAT. $4 \mathrm{I}$ (I933).

${ }^{2}$ Pub. No. 210, 75th Cong. Ist. Sess. (1937) entitled "An Act to create the Farmer's Home Corporation, to promote more secure occlipancy of farms and farm homes, to correct the economic instability resulting from some present forms of farm tenancy, and for other purposes."

Nore: This Act is discussed more extensively in Maddox, The Bankhead-Jones Farm Tenant Act, supra p. 434. ED.

¿ Bankhead-Jones Farm Tenant Act, $\$ 3$ (a). 
From this it is evident that a loan up to $100 \%$ of the purchase price of the farm may be made to a tenant, a larger percentage than in any previous enactment by Congress. Other provisions of the Act include interest at $3 \%$, a term not to exceed forty years and amortization schedules for payment of the principal. For loan funds under this Act, Congress authorized to million dollars for the year ending June 30, 1938, for the following year 25 million and 50 million each year thereafter. These sums should be compared with the amounts used for purchase of land through loans advanced by the Federal Land Banks and the Land Bank Commissioner as shown in Table 2. In only one year, 1935, did agencies under the Farm Credit Administration in their land purchase loans approach the 50 million dollar limit authorized for tenant purchases under the new Act.

With so much activity manifested in the plight of tenant farmers, it is worth pausing a moment to consider the changes in tenants as a percentage of all farmers in recent decades. A glance back at Table $\mathrm{I}$ will show a marked increase, $38.1 \%$ to $42.4 \%$, between 1920 and 1930 . But in 1935 , strange to say, the percentage was lower than in 1930. How can we explain this situation of far reaching legislation in behalf of tenancy and at the same time a decline in tenancy? Have the Land Bank Commissioner loans authorized by the Emergency Farm Mortgage Act of 1933 been responsible? Probably not. The answer is to be found in a breakdown of the United States figures into those for smaller areas. Tenancy figures for the South, including 16 states, reveal a drop in tenancy from 55.5 to 53.5 in the five years ending in 1935. The other 32 states, in the same period, experienced an increase in tenancy from 28.5 to $30.6 .^{40}$

As J. D. Black and R. H. Allen state in their article on the Growth of Farm Tenancy in the United States, the national average for 1935 is misleading. ${ }^{41}$ As they point out, every state outside of the South, save one (New Mexico), showed an increase in tenancy between 1930 and 1935 . In reality, then, the trend toward increasing tenancy is still in operation.

\section{WhAT OF THE Future?}

Fortified with two separate and distinct credit systems for promoting farm ownership the federal government is now in a position to make a determined stand against the long-time trend toward tenancy. It is, of course, too soon to prophesy with much assurance the outcome of the two recent measures which have provided and liberalized governmental farm credit. Nevertheless, there are some probable developments that merit our consideration.

In the first place, there is danger of credit being extended on too generous a scale. For examples we do not have far to go; the outcome of state farm mortgage

10 U. S. Bureau of the Census, U. S. Census of Agriculture, 1935, pp. 104-107.

41 (May, 1937) 51 Q. J. EcoN. 393, especially 416-417. The reader is also referred to the extensive report, Farm Tenancy, Report of the President's Committee (Nat. Resources Committee, 1937). See particularly the sections on growth of tenancy and land-purchase programs of Ireland and Denmark: (pp. 75-79). 
systems in South and North Dakota and in Minnesota indicate the heavy losses that may be experienced. Of course, it can be argued, that the losses of the state systems, and, to this should be added the difficulties of the Federal Land Banks, ${ }^{42}$ were due mainly to the severe depression. Even if this is admitted, the question still remains why the state systems had such terrific losses; in many cases, the losses occurring before the price decline of I93 I had begun. Unfortunately, there is slight chance of escape from optimism in the administration of state farm credit. Whereas private credit agencies are inclined to be conservative in advancing funds, the state agencies have a tendency to liberalize rather than the reverse because otherwise they would be found guilty of lacking faith in the future of their own commonwealth. And what state is there that does not vision a rosier picture of its agricultural future than outsiders can see? The danger, then, is too much optimism. We have observed how the states lost out because of it. What will happen to the federal government? Will it succumb to the same temptation? It has, to a limited extent, as we have seen in the record of the federal irrigation projects.

In comparison with the states the federal government is in a better position to extend loans on farm land. The government at Washington, D. C. can be more "hard-boiled" and conservative because it is farther away from the local "hot spot." It can resist the pressure of some locality wanting to boost its land values whereas a state agency might not be as successful. But whether the federal government in the new loans under the Farm Tenant Act can throw up adequate safeguards around advances up to $100 \%$ of the purchase price of the land is a question time alone can tell.

Secondly, politics and farm credit do not mix well. Farm credit relief measures are a sure hit with Congressmen. One of the lessons to be learned from the government's credit system from I800 to I820 was the hearty appetite Congress had for legislation relieving the debt situation among farmers. A review of state and national legisiative activities in the last five years furnishes another convincing illustration of this same tendency. In all frankness, therefore, it appears that legislatures, both state and national, will treat farm credit more in a political than in a strict financial manner. A çontrast is the Federal Reserve System set up by Congress in 1913. Although politics in a degree may have entered into the establishment and administration of this body, it has been unusually free from subsidies of the kind Congress has linked with the Farm Credit Administration. Although an important function of the Federal Reserve Banks is lending to member banks, there is little evidence of the Reserve Banks having mixed too much optimism with such loans; in fact, the Banks have been accused of the reverse, of being too conservative. There is, as can be seen readily, a good reason for farm credit being good politics as compared with the Federal Reserve Banks; it is simply that farm credit affects many voters and affects them directly.

\footnotetext{
12 Congress came to the rescue of the Federal Land Banks in January, I932 with an act which added 125 million dollars to their capital.
} 
Finally, what of the prospects of governmental farm credit reducing tenancy? At the present, they do not look particularly bright. If we assume 100 million dollars is loaned annually, a liberal estimate, one-half by the Farm Credit Administration through the Federal Land Banks and the Land Bank Commissioner, and the other half by the Secretary of Agriculture as authorized by the Farm Tenant Act, even this amount will not have much effect. How small this sum is in comparison to the job to be done can be visualized by reference to the value of tenant-operated land in 1935, as stated in the Federal Census, $\$ 10,952,747,497$. In 1930, the figure was over 16 billion dollars. Although roo million dollars would speed the attainment of ownership for a small group of tenants, it should not be overlooked that this sum is equal to approximately only one percent of the value of land and buildings on tenant-operated farms. Of course, since many tenants are not in a position to tackle ownership or do not desire it, governmental credit may supply all the credit really needed for this purpose. Maybe, after all, we should consider at least one-third of the farms in the tenant status as a normal condition. Looked at from this viewpoint, governmental farm credit, even though it does not reduce tenancy, can be considered successful if it prevents a continuation of the trend toward tenancy.

What of the prospects for payments under the 1933 and 1937 legislation? One factor has favored the government in the Land Bank Commissioner loans since 1933; they were made on a comparatively low price level, comparatively low for example in terms of the 1926 level. Consequently the loans, although representing amounts up to $75 \%$ of the value of the property, are in absolute amounts not much larger, if any, than the 50\% loans of 1o years ago. As the sale value of land rises, however, excessive loans may occur unless appraisals are kept down. The main objective becomes, then, one of keeping governmental agencies from following rising sale values in their land appraisals.

Difficulties introduced by rising land values suggest the central difficulty in farm credit, fluctuations in the price level. If the price level could be stabilized widespread distress, similar to that in the period I931-I935, could be largely avoided. Without such stability a large element of uncertainty is going to exist concerning the success of governmental agencies in assisting tenants into ownership. For without price stability, those tenants who attempt ownership on anything approaching a $100 \%$ credit basis will be in financial hot water if, soon after they buy, the price level takes a sizeable dip. Congress will, undoubtedly, come to the rescue of these farmers. But even so, it will only provide, in all probability, an opportunity for these farmers to continue carrying a heavy debt burden on somewhat easier terms. If prices, therefore, are to be allowed to fluctuate widely, the future of governmental farm credit will contain many headaches for farmers as well as for credit officials.

Since it is by no means certain that the price level can be satisfactorily corralled and controlled, perhaps we should cast in some other direction to improve the tenant's status. One solution is to make tenancy more attractive; another, to have the government buy land and rent it to farmers on long term leases. Still another is to 
adjust the financing of land to the fluctuations of the price level. This last suggestion, probably, would be the most desirable, but unfortunately it cannot be accomplished without overcoming a number of obstacles.

In adjusting the farmer's debt load to the price level, the chief obstacle is finding a simple method of handling the payments. In the western wheat country, particularly in the prairie provinces of Canada, farmers have purchased land in numerous instances with an agreement to pay a specified portion of the crop to the seller until the principal amount and interest are paid. Suggestions of this type have been made and studied in this country. Johnson at Missouri recently published a bulletin describing a method which he recommends to the farm purchaser as a means of avoiding the risks of changing prices. ${ }^{43}$ An even more radical departure, including payments that would be adjusted to weather variations as well as price variations, is a possibility. The payments, under such a scheme, would be similar to crop share rent payments, with the exception that they would represent a larger portion of the crop and would run for a definite period of years after which the farm would belong to the buyer.

A milestone along the road to needed adjustments was passed when the Farm Credit Act of $1937^{44}$ became a law. One of the provisions in this Act makes it possible for borrowers from the Federal Land Banks and the Land Bank Commissioner to make interest payments in advance. Advances of this kind, instead of applying on principal as formerly, can now be used to build up a reserve fund. This reserve, in turn, will be available to the borrower to use in paying his interest if prices drop or crops fail. Since interest will be paid on advances in the reserve fund, farmers will not be losing by having advances applied in this way rather than on principal.

If governmental credit is to succeed over the long pull either some development of variable payments or stabilization of the price level is essential. Otherwise, the logical answer is withdrawal of governmental credit where it represents an advance of, say, more than $75 \%$ of the farm valuation. In place of this credit, Congress might plan a program to make tenancy more attractive. In the last analysis, if we are to have violent fluctuations of prosperity and depression many tenants would be better off to remain in their present status.

At the beginning of this discussion a question was raised as to the effectiveness of governmental credit in counteracting tenancy. The answer is clear. Up to this time, experience has shown that credit extended by governmental agencies, state and federal, has not been successful in keeping tenancy down. The program now underway, however, is more ambitious than any previous plan. Success in this new credit program is threatened by possible fluctuations in the price level. An attempt should be made either to control or to adjust for these fluctuations else our farm debt difficulties in some future depression may make those of the recent depression seem insignificant.

${ }^{4}$ Johnson, Acquiring Farm Ownership by Payments in Kind, A Plan to Permit Tenants to Buy Farms Through Annual Product Payments, Mo. AGric. Exper. STA., Bull. 378 (January 1937).

"Pub. No. 323, 75th Cong., rst Sess. (r937). 